NATIONAL LABORATORY

\title{
Compendium: Surveys Evaluating Knowledge and Opinions of Hydrogen and Fuel Cell Technologies
}

\section{October 2008}

\author{
Prepared by \\ Tykey Truett \\ Rick Schmoyer \\ Oak Ridge National Laboratory \\ Christy Cooper \\ U.S. Department of Energy
}

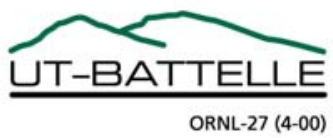




\title{
DOCUMENT AVAILABILITY
}

Reports produced after January 1, 1996, are generally available free via the U.S. Department of Energy (DOE) Information Bridge.

Web site http://www.osti.gov/bridge

Reports produced before January 1, 1996, may be purchased by members of the public from the following source.

\author{
National Technical Information Service \\ 5285 Port Royal Road \\ Springfield, VA 22161 \\ Telephone 703-605-6000 (1-800-553-6847) \\ TDD 703-487-4639 \\ Fax 703-605-6900 \\ E-mail info@ntis.gov \\ Web site http://www.ntis.gov/support/ordernowabout.htm
}

Reports are available to DOE employees, DOE contractors, Energy Technology Data Exchange (ETDE) representatives, and International Nuclear Information System (INIS) representatives from the following source.

Office of Scientific and Technical Information

P.O. Box 62

Oak Ridge, TN 37831

Telephone 865-576-8401

Fax 865-576-5728

E-mail reports@osti.gov

Web site http://www.osti.gov/contact.html

This report was prepared as an account of work sponsored by an agency of the United States Government. Neither the United States Government nor any agency thereof, nor any of their employees, makes any warranty, express or implied, or assumes any legal liability or responsibility for the accuracy, completeness, or usefulness of any information, apparatus, product, or process disclosed, or represents that its use would not infringe privately owned rights. Reference herein to any specific commercial product, process, or service by trade name, trademark, manufacturer, or otherwise, does not necessarily constitute or imply its endorsement, recommendation, or favoring by the United States Government or any agency thereof. The views and opinions of authors expressed herein do not necessarily state or reflect those of the United States Government or any agency thereof. 


\title{
COMPENDIUM: SURVEYS EVALUATING KNOWLEDGE AND OPINIONS OF HYDROGEN AND FUEL CELL TECHNOLOGIES
}

\author{
Tykey Truett \\ Rick Schmoyer \\ Oak Ridge National Laboratory \\ Christy Cooper \\ U.S. Department of Energy
}

October 2008

Prepared by

OAK RIDGE NATIONAL LABORATORY

Oak Ridge, Tennessee 37831-6283

managed by

UT-BATTELLE, LLC

for the

U.S. DEPARTMENT OF ENERGY

under contract DE-AC05-00OR22725 



\section{CONTENTS}

Page

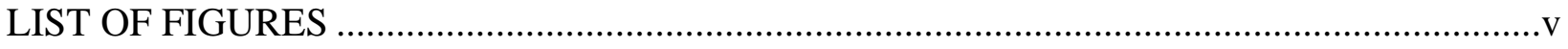

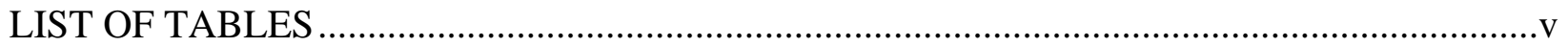

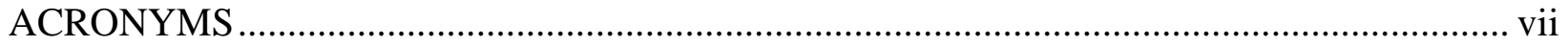

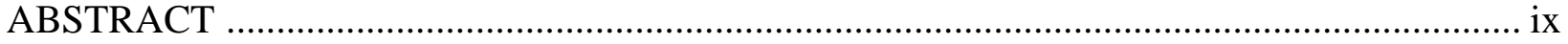

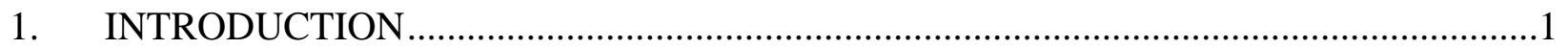

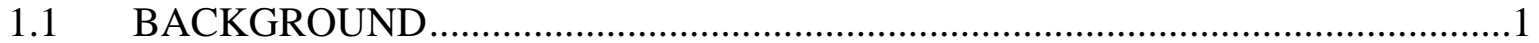

1.2 PURPOSE OF THE UPDATED LITERATURE REVIEW ......................................

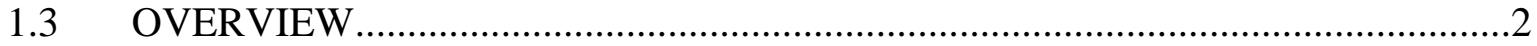

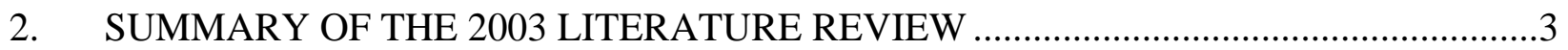

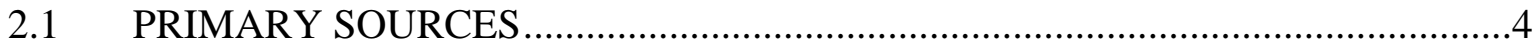

2.2 APPLICABILITY TO DOE TARGET POPULATIONS ………………………......

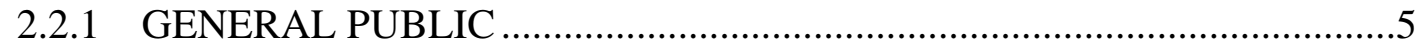

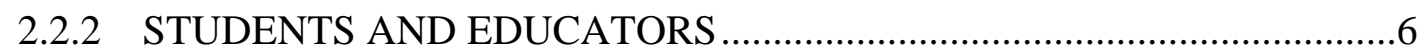

2.2.3 STATE AND LOCAL AGENCIES.........................................................6

2.2.4 POTENTIAL END USERS (INDUSTRY) ……………..............................6

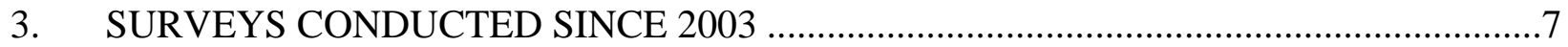

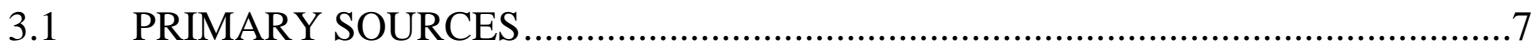

3.1.1 SURVEYS CONDUCTED IN EUROPE ...............................................10

3.1.2 SURVEYS CONDUCTED IN NORTH AMERICA.....................................15

$3.2 \quad$ FOCUS GROUPS AND NON-SCIENTIFIC POLLS .............................................20

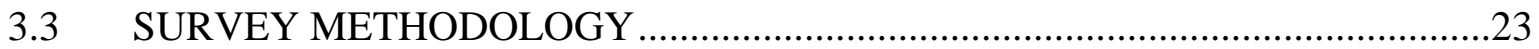

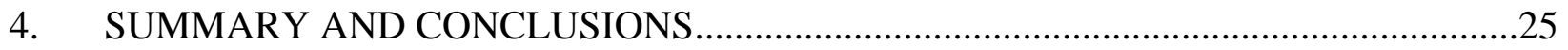

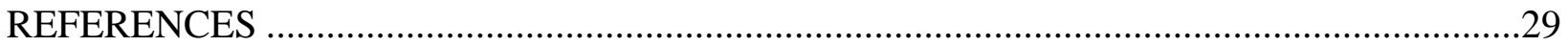





\section{LIST OF FIGURES}

Figure

Page

3.1 A comparison of responses, over time, to a question concerning the best fuel to replace gasoline

3.2 A comparison of responses, over time, to a question concerning the worst fuel to replace gasoline

\section{LIST OF TABLES}

Table

Page

2.1 Overview and comparison of primary sources included in the 2003 literature review...........3

3.1 Overview and comparison of primary sources included in the 2008 compendium ................7

3.2 Overview and comparison of focus groups and non-scientific polls included in the 2008 compendium 



\section{ACRONYMS}

$\begin{array}{ll}\text { AcceptH2 } & \text { Acceptance of Hydrogen } \\ \text { CaFCP } & \text { California Fuel Cell Partnership } \\ \text { CATI } & \text { Computer Assisted Telephone Interview } \\ \text { CUTE } & \text { Clean Urban Transport for Europe } \\ \text { DOE } & \text { Department of Energy } \\ \text { E } & \text { Europe } \\ \text { EU } & \text { European Union } \\ \text { GM } & \text { General Motors } \\ \text { HTAP } & \text { Hydrogen Technical Advisory Panel } \\ \text { ISO } & \text { International Organization for Standardization } \\ \text { NA } & \text { North America } \\ \text { RDD } & \text { Random digit dialing } \\ \text { SHEC } & \text { Sustainable Hydrogen Energy Consortium } \\ \text { TC } & \text { Technical Committee } \\ \text { UK } & \text { United Kingdom } \\ \text { U.S. } & \text { United States } \\ \text { U.S.A. } & \text { United States of America }\end{array}$





\section{ABSTRACT}

This compendium updates a 2003 literature review of surveys of knowledge and opinions of hydrogen and fuel cell technologies. Its purpose is to ensure that results of comparable surveys are considered in surveys conducted by the U.S. Department of Energy (DOE). The first DOE hydrogen and fuel cell knowledge and opinions survey was conducted in 2004. More than twice as many studies related to the 2004 DOE survey have been published since 2003 than were published prior to that date. The fact that there have been significantly more studies implies that there have been additional demonstration projects and/or increased interest in hydrogen and fuel cell technologies.

Fifteen new surveys related to hydrogen and fuel cell knowledge and opinions have been conducted since 2003. All of these surveys were conducted in Europe (E) or North America (NA), and the relevant findings are as follows:

1. Respondents who are more educated are more accepting of hydrogen technologies (NA).

2. Respondents who are more knowledgeable about hydrogen and/or fuel cells are more accepting of hydrogen technologies (E, NA).

3. When asked about issues of trust, respondents generally expressed distrust of the government or political parties but trusted scientists and environmental protection organizations (E).

4. Technical knowledge about hydrogen and fuel cell technologies is low (E, NA).

5. Respondents may express opinions about a technology even when they are lacking in knowledge of that technology (E).

6. Women and men have different priorities when deciding on an automobile purchase (E).

7. Public acceptance of hydrogen is vulnerable to perceptions of decreased safety (E, NA).

8. Public acceptance of hydrogen is vulnerable to perceptions of increased cost (E, NA).

The DOE surveys are similar to other surveys that examine technical knowledge of hydrogen and fuel cell technologies, although the technical questions are different. The DOE surveys are also similar to other opinion surveys in that they address many of the same issues, such as safety, sources of energy information, or trust.

There are many differences between the surveys reviewed in this compendium and the DOE surveys.

- The information for many of the surveys reviewed in this compendium was collected face-toface or electronically; however, all of the DOE hydrogen and fuel cell knowledge and opinions surveys were conducted via telephone interviews.

- Most of the surveys concentrated on a specific population group, while the DOE surveys addressed five different populations (general public, students, government agencies, end users, and safety and codes officials).

- No survey (except the DOE survey) conducted since 2003 surveyed students' knowledge and opinions of hydrogen and fuel cells. 
- Although several surveys have solicited opinions of "users” (e.g., passengers of fuel-cell vehicles), no surveys were conducted of "end users" (industrial users needing large power supplies, commercial users needing uninterrupted power, or transportation businesses).

- While the International Organization for Standardization (ISO) has surveyed its membership concerning standards, the population of safety and codes officials has not been surveyed.

The greatest impact and importance of the DOE surveys is that five distinct population groups are surveyed for both knowledge and opinions on hydrogen and fuel cells. Knowledge levels can be computed for each population group and can be compared across the populations and across time. Opinions can be compared with knowledge levels. A baseline of knowledge levels was derived using the results of the 2004 surveys; this baseline will be compared with the results of the knowledge evaluation for the surveys of 2008/2009 and 2011/2012. The DOE knowledge and opinions surveys are unique in coverage and purpose.

It must be noted that response rates for telephone surveys have decreased dramatically over time. Developments in survey methodology research will have to be followed over the next few years so that necessary adjustments are made in the 2011/2012 DOE hydrogen survey design, to account for cell-phone-only individuals as well as other changes in telephone usage demographics. 


\section{INTRODUCTION}

The mission of the U.S. Department of Energy (DOE) Hydrogen Program is to reduce oil use and carbon emissions in the transportation sector and to enable clean, reliable energy for stationary and portable power generation. The Program seeks to accomplish this mission by supporting a comprehensive and focused portfolio of research, development, and demonstration (RD\&D) activities that address barriers to producing, storing, delivering, and using hydrogen in an efficient, clean, safe, reliable, and affordable manner. While RD\&D is DOE's central mission, technology development alone is not a sufficient condition for commercialization. Other factors, such as regulatory status, market acceptance, level of consumer awareness, supplier manufacturing capabilities, and existing policies and incentives will play a big role in whether or not companies choose to go forward with commercialization. To address these factors, DOE conducts underlying safety research, facilitates and coordinates the activities of codes and standards development organizations, supports efforts in market transformation, and conducts public outreach and education activities (U.S. DOE/DOT, 2006).

\subsection{BACKGROUND}

In 2004, DOE conducted scientific surveys of four populations (the general public, ages 18 and over; students, ages 12-17; state and local government officials; and potential hydrogen end users). The surveys measured knowledge levels and opinions concerning hydrogen and fuel cell technologies within the United States. Survey results were analyzed to establish a baseline of knowledge and understanding (Schmoyer, Truett and Cooper, 2006). The survey results were intended to serve (1) as a reference for designing a hydrogen education program, and (2) as a baseline for measuring changes in understanding and awareness over time. The surveys will be repeated in 2008/2009 and 2011/2012. ${ }^{1}$

Prior to designing the 2004 knowledge and opinions surveys, a literature review was conducted (Truett, 2003). The review summarizes the results of surveys concerning knowledge, attitudes, and/or opinions toward hydrogen. Eight primary data sources were reviewed, two of which were studies based in Europe. Studies involved both closed-end and open-end questions; surveys varied in length from three questions to multi-page interviews. Populations involved in the studies were primarily adults, although one study involved students. The number of participants ranged from 13 to over 16,000 per study. In addition to the primary surveys, related studies were mined for pertinent information.

The 2003 literature review concluded that the public knew very little about hydrogen and fuel cell technologies but was generally accepting of the potential for hydrogen use. In general, respondents considered themselves as environmentally conscious. The public considered safety as the primary issue surrounding hydrogen as a fuel, although price, performance, and convenience were also considerations.

\footnotetext{
${ }^{1}$ It is planned to add a new population group to the 2008/2009 surveys; the new population includes safety and codes officials.
} 


\subsection{PURPOSE OF THE UPDATED LITERATURE REVIEW}

In order to assess the current understanding of hydrogen and fuel cell technologies and applications (information important to developing successful education strategies), the DOE Hydrogen Program plans to repeat the four scientific surveys conducted in 2004. The literature was again searched to ensure that recent information regarding hydrogen and fuel cell knowledge levels and opinions is considered.

The purpose of this compendium is to summarize the results of surveys that have been conducted since the previous literature review was published in October 2003. The compendium emphasizes scientific surveys, but also includes, to a lesser extent, non-scientific polls. At the time of the 2003 literature review, no single survey covered all of the audiences addressed by the DOE knowledge assessment surveys. In addition, no other organization mentioned plans to repeat its survey to assess changes in hydrogen/fuel cell knowledge and opinions. ${ }^{2}$

\subsection{OVERVIEW}

This report contains a brief summary of the findings of the 2003 literature review and a compendium of surveys published since the earlier review. At the time of the 2003 literature review, survey themes concentrated on opinions. Some surveys were specific to attitudes of people who had experienced hydrogen technology - for example, riders on a vehicle powered by hydrogen. Few surveys to determine the existing knowledge base on hydrogen and fuel cells had been conducted and published.

Since 2003, several surveys have been conducted. None were designed to provide the same information as the DOE surveys, and none asked the same set of core questions of the five distinct population groups of interest to the DOE (i.e., general public, students, government agency personnel, end users, and safety and codes officials).

Chapter 2 of this report provides a short description of the primary surveys documented in the 2003 literature review. Chapter 3 provides brief summaries of relevant surveys that have been conducted since 2003. Conclusions of the surveys are discussed in Sections 3.1 and 3.2. Selected aspects of survey methodology are considered in Section 3.3. Chapter 4 summarizes the importance of the recent surveys to the DOE survey.

\footnotetext{
${ }^{2}$ Although definite plans for repeated surveys were not noted, in fact at least one survey has been repeated using the same questions and data collection methodology. Other surveys have been conducted that are very similar in design to the surveys described in the 2003 literature review.
} 


\section{SUMMARY OF THE 2003 LITERATURE REVIEW}

Primary surveys described in the 2003 review include five surveys specifically related to hydrogen and fuel cells. Three additional surveys primarily emphasized energy uses and opinions about the environment. These eight surveys were all statistically designed. Other related studies which were useful in assessing attitudes were also described in the 2003 review. ${ }^{3}$

Full references for the eight primary studies are given below in chronological order, followed by a brief summary. Additional descriptive details are compared in Table 2.1.

\section{Table 2.1. Overview and Comparison of Primary Sources Included in the 2003 Literature Review}

\begin{tabular}{|c|c|c|c|c|c|}
\hline Survey & Site & Population & Responses & Format & Objective \\
\hline $\begin{array}{l}\text { HTAP survey, } \\
1998\end{array}$ & U.S. & $\begin{array}{l}\text { Persons in } \\
\text { research, industry, } \\
\text { government }\end{array}$ & 49 & $\begin{array}{l}\text { Both closed- } \\
\text { and open-end } \\
\text { questions }\end{array}$ & $\begin{array}{l}\text { Evaluation of hydrogen program } \\
\text { elements and identification of } \\
\text { program issues }\end{array}$ \\
\hline $\begin{array}{l}\text { European } \\
\text { Commission } \\
\text { AcceptH2 } \\
\text { survey, } 1998\end{array}$ & Germany & $\begin{array}{ll}\text { - } & \text { Students } \\
\text { - } & \text { Passengers of } \\
\text { hydrogen- } \\
\text { fueled bus }\end{array}$ & $\begin{array}{ll}- & 410 \\
- & 145\end{array}$ & $\begin{array}{l}\text { Both closed- } \\
\text { and open-end } \\
\text { questions }\end{array}$ & $\begin{array}{l}\text { Knowledge about and acceptance } \\
\text { of hydrogen as a fuel; } \\
\text { environmental practices; } \\
\text { comparison of knowledge and } \\
\text { perception of risk }\end{array}$ \\
\hline $\begin{array}{l}\text { Breakthrough } \\
\text { Technologies } \\
\text { survey, } 2002\end{array}$ & U.S. & $\begin{array}{l}\text { - Fuel cell } \\
\text { experts in } \\
\text { academia, } \\
\text { government, } \\
\text { and private } \\
\text { sector } \\
\text { - Hands-on } \\
\text { practitioners }\end{array}$ & - 13 & $\begin{array}{l}\text { Thirteen } \\
\text { questions, } \\
\text { primarily open- } \\
\text { end }\end{array}$ & $\begin{array}{l}\text { General awareness and } \\
\text { understanding of fuel cells; } \\
\text { identification of the education } \\
\text { message }\end{array}$ \\
\hline $\begin{array}{l}\text { Rocky Mountain } \\
\text { Poll, } 2002\end{array}$ & U.S. & $\begin{array}{l}\text { Adults, Maricopa } \\
\text { County, Arizona }\end{array}$ & 603 & $\begin{array}{l}\text { Three questions, } \\
\text { closed-end }\end{array}$ & $\begin{array}{l}\text { Dependence on foreign oil, } \\
\text { willingness to buy hydrogen } \\
\text { vehicle }\end{array}$ \\
\hline $\begin{array}{l}\text { European } \\
\text { Commission } \\
\text { Eurobarometer } \\
\text { survey, } 2002\end{array}$ & $\begin{array}{l}\text { European } \\
\text { Union }\end{array}$ & $\begin{array}{l}\text { Adults }\left(15^{+}\right) \text {, } \\
\text { member states of } \\
\text { the European } \\
\text { Union }\end{array}$ & 16,032 & $\begin{array}{l}\text { Interviews; } \\
\text { primarily open- } \\
\text { end }\end{array}$ & $\begin{array}{l}\text { Public opinion on energy-related } \\
\text { issues, including technologies }\end{array}$ \\
\hline $\begin{array}{l}\text { Transportation } \\
\text { energy surveys, } \\
\text { 2002, 2003 } \\
\text { [Gurikova; } \\
\text { Steiner] }\end{array}$ & U.S. & Adults $(18+)$ & $\begin{array}{l}\text { About } \\
1,000\end{array}$ & $\begin{array}{l}\text { Both closed- } \\
\text { and open-end } \\
\text { questions }\end{array}$ & $\begin{array}{l}\text { Dependence on foreign oil, } \\
\text { knowledge of energy situation, } \\
\text { alternative fuels, and advanced } \\
\text { technologies }\end{array}$ \\
\hline $\begin{array}{l}\text { Millennium Cell } \\
\text { survey, } 2003\end{array}$ & U.S & Adults (18+) & 1,006 & $\begin{array}{l}\text { Nine questions, } \\
\text { closed-end }\end{array}$ & $\begin{array}{l}\text { Preferences and requirements for } \\
\text { hydrogen fuel-powered vehicles; } \\
\text { knowledge of government } \\
\text { subsidies for hydrogen } \\
\text { technologies }\end{array}$ \\
\hline
\end{tabular}

Source: Truett, 2003

\footnotetext{
${ }^{3}$ These related polls suggested that there was a growing interest in the potential of alternative fuels and advanced technologies, that hydrogen was seen as an environmentally friendly fuel, and that the public believed that Congress should legislate requirements for more energy-efficient automobiles; however, they also suggested that the general public was not necessarily willing to pay more for advanced fuel and vehicle technologies.
} 


\subsection{PRIMARY SOURCES}

Hydrogen Technology Advisory Panel (HTAP), Survey Report, May 4, 1998, available from http://www.eere.energy.gov/hydrogenandfuelcells/advisory_panels.html, May 1998.

European Commission, The Acceptance of Hydrogen Technologies, study carried out by Matthias Altmann, Ludwig-Bölkow-Systemtechnik GmbH, Ottobrunn, Germany, and Cornelia Gräsel, Ludwig-Maximilians-Universität München Institute for Educational Psychology, München, Germany, www.hyweb.de/accepth2 , September 1998.

Breakthrough Technologies Institute, Survey Results - Fuel Cell Education Survey, conducted by Bill Frederick Communications, Palm Harbor, Florida, accessible via the FuelCell2000 library at http://www.fuelcells.org/biblio.htm, 2002.

Rocky Mountain Poll, "Reducing U.S. Dependency on Foreign Oil: 35 MPG Requirements and Emerging Hydrogen Fuel Technology Seen as Important Strategies,” Behavior Research Center, Inc., Phoenix, Arizona, Report 2002-IV-14, http://www.brcpolls.com/pra02.htm , November 2002.

European Commission, EUROBAROMETER - Energy: Issues, Options and Technologies, Science and Society, The European Opinion Research Group, http://europa.eu.int/comm/public_opinion/archives/eb/ebs_169.pdf , December 2002.

Transportation Energy Survey 1: Gurikova, Tatyana, Transportation Energy Survey Data Book 1.1, ORNL/SUB/02-4000008627/01, Oak Ridge National Laboratory, Oak Ridge, Tennessee, May 2002.

Transportation Energy Survey 2: Steiner, Elyse, Consumer Views on Transportation and Energy, DRAFT, National Renewable Energy Laboratory, June 2003.

Millennium Cell and U.S. Borax Inc., "Harris Poll Shows Americans' Early Preferences and Requirements for Hydrogen Fuel-Powered Vehicles: Safety, Cost, and Vehicle Range Are Key Consumer Needs," http://www.millenniumcell.com/cgibin/news.pl?function=detail\&id=06112003 , June 11, 2003.

The HTAP poll was addressed to a narrowly defined set of respondents, persons knowledgeable of or interested in the hydrogen economy in the United States. With a small set of respondents to interview and a short list of questions, open-ended comments were encouraged. Similarly, the Breakthrough Technologies survey also had a small set of respondents and requested opinions. The Rocky Mountain poll was conducted within a single county in Arizona; the population surveyed was the general public, and there were only three questions. The European Commission Eurobarometer survey was conducted in Europe and encompassed broader energy concepts than simply hydrogen; it was well-designed for detailed statistical analysis. The Millennium Cell poll was a nationally representative sample of adults and was specifically directed to hydrogen issues. The European Commission survey on the acceptance of hydrogen (AcceptH2), conducted in Germany in 1997-1998, was the only poll that included students. It 
also addressed the acceptance of hydrogen technologies by people who had "experience" with the technology (i.e., passengers on a hydrogen-powered bus). The transportation energy surveys polled public opinions on new fuels and technologies with respect to environmental and policy issues and also compared people's willingness to pay for new technologies.

\subsection{APPLICABILITY TO DOE TARGET POPULATIONS}

The literature review of 2003 was useful when designing the 2004 DOE surveys. Several issues of interest to the DOE education program were addressed, including the following:

- importance of safety, in particular safety of new technologies;

- the knowledge of hydrogen technical facts;

- sources of knowledge and trust in these sources;

- influence of mass media;

- impact of outreach, communication, and demonstration programs to the acceptance of new technologies; and

- opinions about future uses of hydrogen and fuel cell technologies.

Examples of these "lessons learned" are described below for each target population.

\subsubsection{General Public}

The European Commission AcceptH2, Rocky Mountain Poll, European Commission Eurobarometer, transportation energy, and Millennium Cell surveys sought opinions from the general public. When questions on environmental issues were phrased to assess the importance of environmental issues and dependence on imported oil, the public responded that it was very important to protect the environment and reduce dependence on foreign oil. When asked to rank the importance of issues influencing a decision to buy, however, the most important issues were safety, cost, and convenience. Some regional differences were noted in one poll.

Polls agreed that the public lacks knowledge about hydrogen and fuel cell technologies. In the transportation energy survey series, however, the polls indicated that the public's ability to name specific alternative-fuel vehicles increased between 2000-2001-2002. While neither knowledge nor a lack of knowledge of hydrogen technologies correlated strongly with acceptance, acceptance was correlated with experience with the technology.

Two other points addressed in the surveys of the public were (1) where the public obtained information on energy and technologies, and (2) who (i.e., which agencies or organizations) the public believed/trusted. According to the European Commission AcceptH2 survey, only 37\% of the respondents indicated that they had received information on hydrogen technologies. Of these respondents, most indicated that the information had come from the mass media. Respondents of the Eurobarometer study indicated that their primary sources of information on energy-related issues were television (80\%), newspapers, and radio. 


\subsubsection{Students and Educators}

The European Commission AcceptH2 survey included students. Students exhibited very little knowledge about hydrogen. Students indicated that their primary sources of information about hydrogen were mass media and school.

The Breakthrough Technologies survey solicited opinions from academia. The basic message from this survey was that an education program should contain basic, simple messages. This finding reinforces the European Commission AcceptH2 results.

\subsubsection{State and Local Agencies}

The Breakthrough Technologies survey solicited opinions of government personnel.

Respondents to the survey considered policy makers and legislators as very important targets for an education program. There was no consensus about the content of the education program.

HTAP surveyed government personnel who were already involved in hydrogen energy or in areas that could be impacted by hydrogen energy in the future. The respondents indicated that communication at high government levels was poor and that outreach and communication to the public was less than acceptable.

\subsubsection{Potential End Users (Industry)}

The HTAP survey polled persons in industry and government. An area that showed a dichotomy in viewpoints concerned commercialization of hydrogen technologies. One opinion favored long-term renewable-based research and development, while the other favored rapid commercialization of fossil-based technologies. There was also a difference of opinion on the value of demonstration projects.

The Breakthrough Technologies survey included responses from individuals involved in fuel cell development. Although the respondents agreed that applications education is needed, they were unable to identify specific needs. 


\section{SURVEYS CONDUCTED SINCE 2003}

The surveys referenced in this section were found using the Google search engine or were received via email from the authors.

\subsection{PRIMARY SOURCES}

Table 3.1 provides a brief comparison of the populations, number of responses, formats, and objectives of relevant scientific surveys that have been conducted since the literature review of 2003 was published. For the most part, these surveys measured knowledge and/or opinions about hydrogen and/or fuel cell technologies. The DOE surveys conducted in 2004 are included in this table. Additional information about the surveys is provided following the table.

\section{Table 3.1. Overview and Comparison of Primary Sources Included in the 2008 Compendium}

\begin{tabular}{|c|c|c|c|c|c|}
\hline Survey & Site & Population & Responses & Format & Objective \\
\hline \multicolumn{6}{|c|}{ Surveys conducted in Europe } \\
\hline $\begin{array}{l}\text { European } \\
\text { Commission } \\
\text { Eurobarometer } \\
\text { survey, } 2006\end{array}$ & $\begin{array}{l}\text { European Union } \\
\text { ( } 25 \text { members) }\end{array}$ & $\begin{array}{l}\text { Adults }(15+), \\
\text { member states } \\
\text { of the } \\
\text { European } \\
\text { Union }\end{array}$ & 24,815 & $\begin{array}{l}\text { Face-to-face } \\
\text { in-home } \\
\text { interviews; } \\
\text { both open-end } \\
\text { and closed- } \\
\text { end questions }\end{array}$ & $\begin{array}{l}\text { Public opinion on } \\
\text { energy-related issues, } \\
\text { including technologies } \\
\text { related to hydrogen } \\
\text { and fuel cells }\end{array}$ \\
\hline $\begin{array}{l}\text { European } \\
\text { Commission } \\
\text { Eurobarometer } \\
\text { survey, } 2007\end{array}$ & $\begin{array}{l}\text { European Union } \\
\text { (27 members) }\end{array}$ & $\begin{array}{l}\text { Adults }(15+) \text {, } \\
\text { member states } \\
\text { of the } \\
\text { European } \\
\text { Union }\end{array}$ & 25,800 & $\begin{array}{l}\text { Telephone } \\
\text { interviews; } \\
\text { both open-end } \\
\text { and closed- } \\
\text { end questions }\end{array}$ & $\begin{array}{l}\text { Attitudes on issues } \\
\text { related to European } \\
\text { Union policy }\end{array}$ \\
\hline $\begin{array}{l}\text { European } \\
\text { Commission } \\
\text { AcceptH2 surveys } \\
\text { in various cities, } \\
2006\end{array}$ & Europe & $\begin{array}{l}\text { Passengers of } \\
\text { hydrogen- } \\
\text { fueled buses } \\
\text { and other } \\
\text { residents in } \\
\text { four cities in } \\
\text { Europe and one } \\
\text { in U.S. }\end{array}$ & $\begin{array}{l}\text { Before: } \\
\text { 1,358 } \\
\text { After: } \\
1,164\end{array}$ & $\begin{array}{l}\text { Telephone } \\
\text { surveys prior } \\
\text { to and } \\
\text { following } \\
\text { introduction of } \\
\text { hydrogen- } \\
\text { fueled buses; } \\
\text { both closed- } \\
\text { and open-end } \\
\text { questions; }\end{array}$ & $\begin{array}{l}\text { Evaluate public } \\
\text { perceptions and } \\
\text { acceptance of fuel cell } \\
\text { buses and measure } \\
\text { economic preferences } \\
\text { towards the use of } \\
\text { these vehicles }\end{array}$ \\
\hline
\end{tabular}




\section{Table 3.1. Overview and Comparison of Primary Sources Included in the 2008 Compendium}

\begin{tabular}{|c|c|c|c|c|c|}
\hline Survey & Site & Population & Responses & Format & Objective \\
\hline $\begin{array}{l}\text { The Society of } \\
\text { Motoring } \\
\text { Manufacturers and } \\
\text { Traders, } 2007\end{array}$ & Great Britain & $\begin{array}{l}\text { Car owners in } \\
\text { Great Britain }\end{array}$ & $\begin{array}{l}805 \\
\text { (telephone); } \\
19 \text { (focus } \\
\text { groups) }\end{array}$ & $\begin{array}{l}\text { Two parts: } \\
\text { quantitative } \\
\text { telephone } \\
\text { survey; two } \\
\text { discussion } \\
\text { groups }\end{array}$ & $\begin{array}{l}\text { To gain a greater } \\
\text { understanding of } \\
\text { women's roles in } \\
\text { motor industry, e.g., } \\
\text { buying habits }\end{array}$ \\
\hline $\begin{array}{l}\text { Netherlands } \\
\text { surveys, Delft } \\
\text { University of } \\
\text { Technology, } 2004\end{array}$ & Netherlands & Dutch citizens & 612 adults & $\begin{array}{l}\text { Face-to-face } \\
\text { interviews: } 1 \\
\text { open-end } \\
\text { question, } 9 \\
\text { closed-end } \\
\text { knowledge } \\
\text { questions, and } \\
7 \text { check-list } \\
\text { questions }\end{array}$ & $\begin{array}{l}\text { Examine public } \\
\text { reactions to "colored" } \\
\text { information and } \\
\text { evaluate willingness to } \\
\text { use hydrogen in } \\
\text { specific applications }\end{array}$ \\
\hline $\begin{array}{l}\text { NOW/SenterNovem } \\
\text { Project; CATO } \\
\text { program, 2004- } \\
2005\end{array}$ & Netherlands & Dutch citizens & $\begin{array}{l}\text { Three } \\
\text { surveys: } \\
327, \\
300 \\
995\end{array}$ & $\begin{array}{l}\text { Questionnaires } \\
\text { completed on } \\
\text { home } \\
\text { computers } \\
\text { (two } \\
\text { traditional } \\
\text { format; one } \\
\text { information } \\
\text { choice) }\end{array}$ & $\begin{array}{l}\text { Investigate the impact } \\
\text { of pseudo opinions on } \\
\text { survey results when } \\
\text { assessing opinions of } \\
\text { new technologies }\end{array}$ \\
\hline Haraldsson, 2004 & $\begin{array}{l}\text { Stockholm, } \\
\text { Sweden }\end{array}$ & $\begin{array}{l}\text { Passengers and } \\
\text { drivers of fuel } \\
\text { cell buses }\end{array}$ & $\begin{array}{l}518 \\
\text { passengers; } \\
23 \text { drivers }\end{array}$ & $\begin{array}{l}\text { Face-to-face } \\
\text { closed-end } \\
\text { survey } \\
\text { conducted of } \\
\text { on-board } \\
\text { passengers }\end{array}$ & $\begin{array}{l}\text { Assess knowledge and } \\
\text { attitudes, and evaluate } \\
\text { willingness to pay; } \\
\text { assess driving } \\
\text { experience of drivers }\end{array}$ \\
\hline $\begin{array}{l}\text { Maack, } \\
2004\end{array}$ & $\begin{array}{l}\text { Reykjavik, } \\
\text { Iceland }\end{array}$ & $\begin{array}{l}\text { Passengers of } \\
\text { fuel cell and } \\
\text { diesel buses, } \\
\text { persons living } \\
\text { along the bus } \\
\text { route, and } \\
\text { pedestrians }\end{array}$ & 200 & $\begin{array}{l}\text { Face-to-face } \\
\text { interviews; } 9 \\
\text { closed-end } \\
\text { and } 3 \text { open- } \\
\text { end questions }\end{array}$ & $\begin{array}{l}\text { Assess the social } \\
\text { acceptance of } \\
\text { hydrogen as a fuel }\end{array}$ \\
\hline \multicolumn{6}{|c|}{ Surveys conducted in North America } \\
\hline $\begin{array}{l}\text { Schmoyer, Truett, } \\
\text { and Cooper, } 2006\end{array}$ & U.S. & $\begin{array}{l}\text { General public, } \\
\text { students, state } \\
\text { and local } \\
\text { government } \\
\text { agencies, end } \\
\text { users }\end{array}$ & $\begin{array}{l}\text { Targeted } \\
\text { survey } \\
\text { sizes: } \\
1,000 \\
1,000 \\
246 \\
99 \\
\end{array}$ & $\begin{array}{l}\text { Telephone } \\
\text { surveys: } \\
\text { closed-end } \\
\text { questions -- } \\
\text { some common } \\
\text { to all four } \\
\text { populations } \\
\end{array}$ & $\begin{array}{l}\text { For four distinct } \\
\text { populations, assess the } \\
\text { baseline knowledge of } \\
\text { and determine } \\
\text { opinions about } \\
\text { hydrogen and fuel cell } \\
\text { technologies }\end{array}$ \\
\hline $\begin{array}{l}\text { Collantes, } \\
\text { Hydrogen Policy } \\
\text { Survey, } 2005\end{array}$ & $\begin{array}{l}\text { Online survey; } \\
\text { request for } \\
\text { participation } \\
\text { sent worldwide; } \\
\text { most responses }\end{array}$ & $\begin{array}{l}\text { Primarily } \\
\text { databases of } \\
\text { attendees to } \\
\text { conferences } \\
\text { related to }\end{array}$ & $\begin{array}{l}490 \text { usable } \\
\text { responses }\end{array}$ & Email survey & $\begin{array}{l}\text { Collection of policy } \\
\text { beliefs from all sectors } \\
\text { of the policy process } \\
\text { related to hydrogen }\end{array}$ \\
\hline
\end{tabular}


Table 3.1. Overview and Comparison of Primary Sources Included in the
2008 Compendium

\begin{tabular}{|c|c|c|c|c|c|}
\hline Survey & Site & Population & Responses & Format & Objective \\
\hline & from U.S. & hydrogen & & & \\
\hline $\begin{array}{l}\text { General Motors } \\
\text { survey, } 2005\end{array}$ & United States & $\begin{array}{l}\text { Cross section } \\
\text { of adults }\end{array}$ & 1,004 & $\begin{array}{l}\text { Telephone } \\
\text { survey }\end{array}$ & $\begin{array}{l}\text { Explore Americans' } \\
\text { attitudes toward U.S. } \\
\text { energy policy and } \\
\text { emerging automotive } \\
\text { technologies, } \\
\text { including hydrogen } \\
\text { vehicles }\end{array}$ \\
\hline $\begin{array}{l}\text { TNS Automotive } \\
\text { survey for } \\
\text { California Fuel Cell } \\
\text { Partnership, } 2007\end{array}$ & U.S. & $\begin{array}{l}\text { Respondents } \\
\text { recruited using } \\
\text { the TNS online } \\
\text { panel }\end{array}$ & $\begin{array}{l}816 \\
\text { licensed } \\
\text { drivers in } \\
\text { California }\end{array}$ & $\begin{array}{l}\text { Telephone } \\
\text { survey of } \\
\text { respondents } \\
\text { recruited using } \\
\text { the TNS } \\
\text { online panel }\end{array}$ & $\begin{array}{l}\text { Gain insight on the } \\
\text { general attitudes about } \\
\text { alternative fuels in } \\
\text { California, including } \\
\text { hydrogen }\end{array}$ \\
\hline $\begin{array}{l}\text { Canada ridership } \\
\text { survey, } 2007\end{array}$ & $\begin{array}{l}\text { Winnipeg, } \\
\text { Manitoba, } \\
\text { Canada }\end{array}$ & $\begin{array}{l}\text { Riders of a } \\
\text { hydrogen } \\
\text { hybrid bus }\end{array}$ & 369 & $\begin{array}{l}\text { Face-to-face } \\
\text { interviews; } \\
\text { both closed- } \\
\text { and open-end } \\
\text { questions } \\
\end{array}$ & $\begin{array}{l}\text { Public acceptability of } \\
\text { hydrogen bus in cold } \\
\text { weather }\end{array}$ \\
\hline Patterson, 2007 & U.S. & $\begin{array}{l}\text { Adults in the } \\
\text { U.S. }\end{array}$ & 1,022 & $\begin{array}{l}\text { Telephone } \\
\text { survey; both } \\
\text { closed- and } \\
\text { open-end } \\
\text { questions }\end{array}$ & $\begin{array}{l}\text { Obtain opinions on } \\
\text { best and worst fuels } \\
\text { for the future }\end{array}$ \\
\hline Shaheen, 2007 & $\begin{array}{l}\text { U.S. - } \\
\text { California and } \\
\text { Michigan }\end{array}$ & $\begin{array}{l}\text { Fleet drivers of } \\
\text { a hydrogen fuel } \\
\text { vehicle fleet }\end{array}$ & $\begin{array}{l}65 \text { (49 } \\
\text { participants } \\
\text { completed } \\
\text { all three } \\
\text { phases); six } \\
\text { participants } \\
\text { in focus } \\
\text { group }\end{array}$ & $\begin{array}{l}\text { Written } \\
\text { questionnaire } \\
\text { completed on- } \\
\text { line; } \\
\text { longitudinal (7 } \\
\text { months) } \\
\text { survey design; } \\
\text { also one focus } \\
\text { group }\end{array}$ & $\begin{array}{l}\text { To assess drivers' } \\
\text { attitudes and } \\
\text { perceptions }\end{array}$ \\
\hline
\end{tabular}

The first three surveys in the section on surveys conducted in Europe are updates to surveys in the 2003 literature review. In the section on surveys conducted in North America, the survey results reported by Patterson (2007) provided updated data to the transportation surveys reported in the 2003 literature review.

In some cases (e.g., the AcceptH2 surveys), citations to multiple articles are provided. These citations are related to the same set of surveys, although they may discuss different perspectives on the survey findings. 


\subsubsection{Surveys Conducted in Europe}

\section{Eurobarometer Studies}

- European Commission. Eurobarometer: Energy Technologies: Knowledge, Perception, Measures. ISSN 1019-5593. http://ec.europa.eu/research/energy/pdf/energy_tech_eurobarometer_en.pdf (2006).

- European Commission. Flash Eurobarometer: Attitudes on Issues Related to EU Energy Policy: Analytical Report. Flash EB Series \#206. http://ec.europa.eu/public_opinion/flash/fl206a_en.pdf (2007).

The Eurobarometer is a statistically designed and analyzed survey. The 2006 survey had a similar purpose to the Eurobarometer survey from 2002 and the methodology was very similar; however, the survey questions were different. The purpose of the Eurobarometer survey was to assess citizens' knowledge, attitudes, and perceptions of energy issues.

Between May and June 2006, respondents were interviewed in all 25 countries of the European Union; a total of 24,815 individuals age 15 or over were interviewed using a scientific sampling methodology. Questions addressed perception, knowledge, and attitudes toward energy issues, among other energy-related topics. Over half (53\%) had heard of "hydrogen energy and cars" in the context of energy production, and $41 \%$ had heard of fuel cells. Knowledge of individual energy production technologies was claimed more often by males than by females. When asked about the most used energy sources, Europeans responded that oil and gas were the most used. Interviewees were presented a list of specific sources of information and asked how much they trusted each source to give them information. The majority of European citizens trusted scientists (71\%) and environmental protection organizations (64\%). The national government and political parties are trusted the least (29\% and $13 \%$, respectively). Respondents are most in favor of renewable energy sources (solar, wind, hydroelectric, ocean energy); $37 \%$ of the respondents indicated that they were opposed to nuclear energy. Although fuel cells were mentioned in this survey, hydrogen was mentioned only in terms of "hydrogen energy and cars," and was not addressed as a separate topic.

In early 2007, a survey was conducted to assess the extent to which Europeans are concerned about climate change and support actions to combat global warming. Results indicated that $82 \%$ of Europeans are well aware that the way energy is produced and consumed has a negative impact on climate. Findings also indicated that citizens are certain that energy prices will increase significantly over the next decade. There were no specific questions on hydrogen or fuel cell technologies.

\section{European Commission AcceptH2 Project}

- Altmann, Matthias, Patrick Schmidt, Tanya O’Garra, David Hart, Susana Mourato, Carsten Rohr, Marcello Contestabile, Bob Saynor, Lisa Garrity, Cornelia Graesel, Anne Beerenwinkel, Ken Kurani, Marshall Miller, Jaimie Levin, and Simon Whitehouse. "AcceptH2: Public Perception of Hydrogen Buses in Five Countries." International German 
Hydrogen Energy Congress 2004, Essen, Germany.

http://www.acceptH2.com/results/docs/H2Congress2004_manuscript.pdf (February 2004).

- Altmann, Matthias, Patrick Schmidt, Reinhold Wurster, Tanya O’Garra, Susana Mourato, Lisa Garrity, Cornelia Graesel, Anne Beerenwinkel, and Simon Whitehouse. “AcceptH2: Public Acceptance and Economic Preferences Related to Hydrogen Transport Technologies in Five Countries.” 156h World Hydrogen Energy Conference, Yokohama, Japan. http://www.acceptH2.com/results/docs/AcceptH2_WHEC15_LBST_June2004_manuscript.p df (2004).

- O’Garra, T, S. Mourato, and P. Pearson. “Analysing Awareness and Acceptability of Hydrogen Vehicles: A London Case Study.” International Journal of Hydrogen Energy. 30(6): 649-659 (2005).

- O’Garra, Tanya. AcceptH2 Full Analysis Report: Comparative Analysis of the Impact of the Hydrogen Bus Trials on Public Awareness, Attitudes and Preferences: A Comparative Study of Four Cities - Public Acceptance of Hydrogen Transport Technologies. Work Package 6, Deliverable 9, http://www.accepth2.com/results/docs/AcceptH2_D9_Full-AnalysisReport 050804.pdf (August 2005).

- Garrity, Lisa. "Complexities Influencing the Introduction of Sustainable Transport Technologies,” http://www.dpi.wa.gov.au/mediaFiles/alt_conflisagarrity.pdf (September 2006).

The AcceptH2 surveys were originally intended to be conducted in five cities - London, England; Berlin, Germany; Luxembourg, Luxembourg; Perth, Australia; and Oakland, California, U.S.A. Each of these cities had hydrogen-fueled bus demonstration projects. The survey design was to conduct surveys before the demonstration project started and again after the introduction of the hydrogen buses in the cities. Because the post-survey was not conducted in Oakland, the final report only provides results of the European surveys. The ex-ante surveys were conducted in the four cities in Europe between July 2003 and February 2004, the ex-post surveys about one year later. ${ }^{4}$

Ex-post survey respondents were more knowledgeable about hydrogen vehicles than ex-ante respondents (based on responses of first-time respondents not on board a hydrogen bus) in all four cities. This increase in knowledge may not be reliable, however, because responses to some questions indicated that the respondents did not pay full attention to the questions.

Findings indicate that public attitudes were overall quite positive toward the introduction of hydrogen buses. In addition, over half of all bus users in all the city samples supported offering hydrogen at a local fueling station. With regard to general opinions about alternative energies, the AcceptH2 surveys found that theoretical support for renewable energies may not reflect people's actual attitudes toward hydrogen in their local area, and that opposition toward technological solutions may be rooted in opposition to the company behind the application rather than to the technology.

\footnotetext{
${ }^{4}$ The term "ex ante" is Latin for "beforehand," and the term "ex post" is Latin for "after the fact." These terms are used in models where there is uncertainty that is resolved during the course of events. Ex ante values are calculated prior to the resolution of uncertainty, and ex post values are calculated after the uncertainty has been resolved. For more information, see the Economics Glossary at http://economics.about.com .
} 


\section{The Society of Motoring Manufacturers and Traders}

- Ipsos MORI. Women and Motoring: A Research Study on Behalf of the Society of Motoring Manufacturers and Traders. http://smmtlib.findlay.co.uk/articles/homepagearticle/HomePageArticles/Women\%20and\%2 0Motoring\%20Final\%20report_16th\%20May\%202007.pdf (May 2007).

The Society of Motoring Manufacturers and Traders commissioned a study to gain an understanding of women's role in the motor industry, especially with respect to buying habits and changes in these buying habits through different life stages.

The study used a telephone omnibus survey (805 interviews conducted with car owners in Great Britain, April 13-15, 2007) and two focus groups (women only, 10 participants under 40 years of age; nine participants 40 and over, April 16, 2007). The importance of this study to DOE is the impact of women as decision makers in the automobile market. The conclusion of the study is that price, appearance, and brand are important features to women. Safety features and low carbon emissions are of lower importance.

\section{Netherlands Surveys, Delft University of Technology}

- Zachariah-Wolff, J. Leslie and Kas Hemmes. "Public Acceptance of Hydrogen in the Netherlands: Two Surveys that Demystify Public Views on a Hydrogen Economy.” Bulletin of Science, Technology \& Society. 32(4): 339-345 (August 2006).

- Zachariah, J. Leslie, Kas Hemmes, and Amish Patil. "The Effect of Knowledge on the Public Acceptance of Hydrogen and Its Potential Applications in the Netherlands: Results of a Survey.” Proceedings International Hydrogen Energy Congress and Exhibition IHEC 2005, Istanbul, Turkey.

- Van den Bosch, Suzanne, Eric Molin, Kas Hemmes, J. Leslie Zachariah, Anish Patil, Caspar Chorus, Wouter Boon, and Nina Dragutinovic. "Public Acceptance of Hydrogen in the Netherlands: Results of a Survey.” Paper Presented at World Hydrogen Energy Conference 2004, Japan.

- Molin, Eric. "Causal Analysis of Hydrogen Acceptance.” Transportation Research Record: Journal of the Transportation Research Board: Energy and Environmental Concerns 2005. 1941: 115-121 (2005)

These reports document various aspects of a survey of 612 adults conducted in the Netherlands during 2004. The survey was divided into two parts. The purpose of the first part was to determine how biased information influences public acceptance of hydrogen; the second part addressed the willingness of the Dutch public to use hydrogen in specific applications. The research noted how knowledge and acceptance differ among age, education, and gender groups.

The survey was conducted by Delft University of Technology students, who approached 612 Dutch citizens randomly in public spaces across the Netherlands. The students asked persons who agreed to take the survey to complete a knowledge assessment. After responding to these knowledge questions, respondents then were asked to read "colored" text (positive, negative, neutral) or were not given additional information (control group). After the information 
intervention, respondents were asked questions about hydrogen perception and their willingnessto-use hydrogen applications.

Results of the Dutch survey indicated that hydrogen technical knowledge was not high, hydrogen was perceived as environmentally friendly, and the willingness to use hydrogen was rather high. Increased costs were a concern for switching to hydrogen, as was the perception of decreased safety. The results of presenting the biased information about hydrogen were as expected; however, the negative text had a much stronger impact than did the positive text. The authors thought that the difference might be caused by the fact that the negative text described the dangers of hydrogen and the positive text described environmental benefits. The results suggest that public acceptance of hydrogen is vulnerable to perceptions of decreased safety. A structural equation model was estimated to examine the likely effects of colored information and other factors influencing hydrogen acceptance. The model suggested that actively providing positive facts about hydrogen, especially to women, may increase the acceptance of hydrogen in the marketplace.

The authors of the Netherlands survey noted that more highly educated respondents have more factual knowledge about hydrogen and a higher hydrogen acceptance. They also noted that older people have a much lower tendency to accept hydrogen than younger people.

\section{NOW/SenterNovem Project; CATO Program}

- de Best-Waldhober, Marjolein, Dancker Daamen, and Andre Faaij. Public Perceptions and Preferences Regarding Large-scale Implementation of Six $\mathrm{CO}_{2}$ Capture and Storage Technologies. NOW/SenterNovem Project and CATP program. March 2006.

- Daamen, Dancker, Marjolein de Best-Waldhober, Kay Damen, and Andre Faaiij, "Pseudoopinions on CCS Technologies," GHGT-8, $8^{\text {th }}$ International Conference on Greenhouse Gas Control Technologies, June 18-22, 2006, Trondheim, Norway.

- de Best-Waldhober, Marjolein, Dancker Daamen, and Andre Faaiij, "Informed Public Opinions on $\mathrm{CO}_{2}$-Capture and Storage Technologies," GHGT-8, 8 th International Conference on Greenhouse Gas Control Technologies, June 18-22, 2006, Trondheim, Norway.

Copies of these articles may be found at http://www.co2cato.nl/modules.php?name=CATO\&page $=19$.

These three papers do not contain results or findings from surveys on hydrogen or fuel cell technologies. The importance of this research is the impact of "pseudo-opinions" on survey results.

Two traditional questionnaires (December 2004, 327 respondents; November 2005, 300 respondents) were administered to the general public on highly technical topics. The surveys were similar to the 2004 DOE surveys in that they asked technical questions to assess knowledge level and also asked opinion questions. Data indicated that the respondents lacked understanding of the technologies addressed by the surveys; indeed, high percentages of the respondents stated that they had never heard of the technologies. Surprisingly, however, the respondents did not hesitate to provide opinions about (evaluations) the technologies. These opinions were labeled 
by the researchers as "pseudo opinions." The researchers asserted that these opinions are unstable and should not be used to guide policy decisions. A third survey (November-December 2004, 995 respondents) was conducted using a different type of questionnaire. This survey, called an information-choice questionnaire, provided information about consequences of different policy options and then asked respondents to evaluate various technologies. Results indicated that the public is much more accepting of new technologies (or technologies that are difficult to understand) if they are informed about (i.e., possess knowledge about) the technologies.

\section{Haraldsson}

- Haraldsson, Kristina. “On Direct Hydrogen Fuel Cell Vehicles Modelling and Demonstration.” [thesis] http://www.diva-portal.org/kth/theses/abstract.xsql?dbid=147 (2005).

The primary theme of this doctoral thesis report was the engineering component, which described vehicle modeling and demonstration projects. The surveys were reported as a component of the overall project.

Surveys were conducted of over 500 fuel cell bus passengers and 23 fuel cell bus drivers in Stockholm, Sweden, in 2004. The buses were part of the Clean Urban Transport for Europe (CUTE) project. Question categories included general information (gender, age, etc.), knowledge about the fuel cell bus project and interest in hydrogen and fuel cells technology, attitudes concerning bus performance and characteristics, key factors about choice of transportation, and willingness to pay a higher fee. Most (77\%) of the respondents knew about the fuel cell bus project; the most common sources of information were newspapers and information at the bus stops. A majority of the passengers (74\%) thought that the technology was safe. While most respondents thought that the buses were less noisy and more comfortable than ordinary buses, $64 \%$ of the passengers indicated unwillingness to pay a higher fee to enable more fuel cell buses to be put in revenue service. Results of the surveys of bus drivers indicated that the driving experience, acceleration, and general comfort were better or similar to those of a conventional bus.

\section{Maack}

- Maack, Maria, Kjartan Due Nielsen, Hlynur Torfi Torfason, Sverrir Orvar Sverrisson, and Karl Benediktsson. ECTOS, Ecological City Transport System, Assessment and Evaluation of Socio-economic Factors. Deliverable No. 12, EVK-CT-2000-00033, Reykjavik, Iceland. http://www.ectos.is/newenergy/upload/files/utgefid_efni/ectos_12-assessement_of_socioeco.pdf (2004).

A short questionnaire was posed to passengers on fuel cell buses (50), passengers on diesel buses (50), persons who lived near the fuel cell bus routes (50), and pedestrians in the city of Reykajvik (50). The questions were primarily of a multiple-choice format; there were also three open-ended questions. Most respondents (92\%) commented positively about the hydrogen bus test in Reykjavik. Almost $86 \%$ of all respondents claimed to be either positive or very positive 
about the possibility that hydrogen will replace oil as the main fuel for buses, cars, and vessels. When asked why they supported hydrogen, $44 \%$ noted less pollution as the reason. In fact, $90 \%$ of respondents thought that hydrogen was a good fuel and associated it with water and a clean environment. When asked about an acceptable price, the people riding the buses indicated that hydrogen costing the same or a lower price than gasoline would be acceptable. Many (over 20\%) of the people on the street or people who lived near the bus lines indicated that a price $10 \%-20 \%$ higher would be acceptable. When asked whether hydrogen was a safe type of fuel, $49 \%$ of the respondents indicated that they did not know, $49 \%$ thought it was safe/very safe, and $2 \%$ thought it was unsafe/very unsafe.

\subsubsection{Surveys Conducted in North America}

\section{Schmoyer, Truett, and Cooper}

- Schmoyer, R. L., Tykey Truett, and Christy Cooper. Results of the 2004 Knowledge and Opinions Surveys for the Baseline Knowledge Assessment of the U.S. Department of Energy Hydrogen Program. ORNL/TM-2006/417 (April 2006).

Statistically designed surveys were conducted of four different populations (general public, students, state and local government agencies, and potential end users). The results of these surveys showed that knowledge of hydrogen and fuel cell technologies is directly related to opinions of the safety of these technologies. In addition, every population group correctly answered a higher percentage of general hydrogen questions than fuel cell questions. The general public survey indicated that safety and cost were considered to be more important than the environment and convenience. The state and local officials scored the highest on technical knowledge, which is to be expected. While all four population groups used television as a primary source of energy information, the internet and science and technology journals are used to a much greater extent by state and local officials use than by the other populations surveyed. One significance of this set of surveys is that they will be repeated in three-year intervals. (See Section 1.1 for additional information regarding this survey.)

\section{Collantes}

- Collantes, Gustavo. The Hydrogen Policy Survey: Descriptive Statistics of the Study Sample and Their Policy Perspectives. Institute of Transportation Studies, University of California, Davis, UCD-ITS-RR-05-21. http://pubs.its.ucdavis.edu/publication_detail.php?id=64 (December 2005).

This paper describes results of an electronic survey about issues related to hydrogen policy. An email survey was sent to a sample of about 4,000 individuals from about 1,450 different organizations in both the United States and other countries. The sample was selected primarily from databases of attendees of hydrogen conferences. A total of 490 usable responses from 323 organizations were received from 23 different countries. About $79 \%$ of the responses were from the United States and about $6 \%$ from Canada. An important fact that arose from the analysis of this survey was that policy activities go beyond the boundaries of the respondent's home country. 
Respondents were asked to provide an agreement rating to policy statements in six general areas. The policy statements receiving the highest and lowest agreement ratings (as measured by the weighted mean) in each general area are provided below.

- General policy-belief statements [on a scale of 1 (strongly disagree) to 5 (strongly agree)]

o "Governments should provide funds for demonstration programs on hydrogen technologies/systems" [mean $=4.202]$

0 "In general, protecting the economy is more important than protecting the environment” [mean = 2.379]

- General policy-preference statements [on a scale of 1 (strongly oppose) to 5 (strongly support)]

o "Increasing fuel efficiency requirements on new light-duty vehicles" [mean = 4.465]

o "A mandate on the quantity/percentage of hydrogen-fueled vehicles produced" [mean $=2.326]$

- Policy preferences on hydrogen production pathways [on a scale of 1 (strongly oppose) to 5 (strongly support)]

o "Solar" [mean $=4.242]$

o “Coal without CO sequestration” [ mean = 1.987]

- Research policy preferences [on a scale of 1 (strongly oppose) to 5 (strongly support)]

o "Hydrogen production from renewable sources of energy" [

o "Hydrogen production from coal” [mean = 3.193]

- Organizations’ interests [on a scale of 1 (not important) to 3 (very important)]

o “Gasoline hybrid electric vehicles" [mean = 2.300]

o “Gasoline internal combustion vehicles" [mean = 1.648]

- Education policy beliefs: This section is of greatest importance to the DOE surveys. Respondents indicated that education programs should be primarily concerned with informing (1) consumers about the economic value of hydrogen vehicles, (2) government agencies about the societal and environmental benefits of hydrogen, and (3) safety and permitting officials about issues related to hydrogen safety.

This survey also asked respondents to name the organizations that they considered the most influential on policies related to hydrogen. The U.S. Department of Energy was mentioned most often by U.S. respondents.

\section{General Motors (GM) Survey}

- Peter D. Hart Research Associates. “Americans' Views of Emerging Automotive Technologies.” http://www.theautochannel.com/news/2005/06/30/136297.html and http://media.gm.com/images/hart_research.pdf (June 30, 2005) 
This survey, conducted for GM June 17-20, 2005, had three purposes - to determine the opinion of U.S. adults regarding the importance of energy independence, to determine public acceptance of new technologies and alternative fuels, and to obtain a measure of public perception of the role of GM in developing energy-efficient vehicles.

Respondents were provided four options and asked which should be the top priority for U.S. energy policy $-43 \%$ of respondents said "reduce dependence on foreign oil;" $20 \%$ said "improve fuel efficiency of vehicles;" 19\% said "reduce pollution and harmful emissions;" and 15\% said "keep fuel costs low." Respondents were asked to identify whether certain statements about automotive technologies were myth or fact. The question "Driving hydrogen-powered vehicle produces no pollution" was answered correctly by $50 \%$ of the respondents. When asked about long-term solutions to the energy crisis, $29 \%$ of the respondents described hydrogen fuel cell vehicles as having the best chance for success. Sixty-five percent of the respondents believe that the U.S. government should make a funding commitment to transform the auto industry into a hydrogen-based system; however, 55\% oppose increasing the gas tax to fund the effort.

\section{TNS}

- TNS Automotive. “California Fuel Cell Partnership - Alternative Fuels Research.” (April 2007) [presentation].

The California Fuel Cell Partnership (CaFCP) authorized a study of licensed drivers in California to gain insight on general attitudes toward six alternative fuels, including hydrogen fuel cells. The study was fielded from March 7-12, 2007, and a total of 816 surveys were completed.

Respondents indicated that, in the future, most vehicles will be powered by a mix of traditional and alternative fuels. They also noted that auto/oil company agendas and public awareness are two of the most important factors hindering progress on alternative fuels. In addition, high cost was cited as significantly hindering hydrogen fuel cell technology.

Respondents consider electricity and conventional gasoline safe; $54 \%$, however, indicated that they require more information on hydrogen fuel cells before deciding on their safety.

The survey found that college-educated respondents know more about alternative fuels. College graduates and high earners (over $\$ 100,000$ ) have the greatest awareness of hydrogen fuel cells. Knowledge about hydrogen fuel cells with respect to emissions, safety, availability, and delivery is low.

About 20\% of the respondents believed that hydrogen fuel cells have zero emissions; $56 \%$ didn't know about the emissions in comparison with conventional fuels. The respondents indicated that the primary advantage of hydrogen fuel cells was benefit to the environment. 


\section{Canada Ridership Survey}

- Hickson, Allister, Al Phillips, and Gene Morales. "Public Perception Related to a Hydrogen Hybrid Internal Combustion Engine Transit Bus Demonstration and Hydrogen Fuel.” Energy Policy. 35: 2249-2255 (2007).

- Phillips, Al, and Allister Hickson. Hydrogen Hybrid Internal Combustion Engine Bus: Winnipeg Ridership Survey. Prepared for Vehicle Technology Centre, University of Manitoba Transport Institute. http://www.gov.mb.ca/iedm/vtci/projects/hydrogen/report/hbus05_report.pdf (March 2005).

This research focused on public acceptance of hydrogen in a hybrid internal combustion engine in cold weather conditions (Winnipeg, Manitoba, Canada) in March 2005. The bus was operated on a typical for-fare route. Interviewers stationed on the bus requested participation in the survey, which was completed by riders during the trip. Interviewers ensured that duplication of survey responses was avoided by screening. The survey had both closed-ended and open-ended responses. A total of 369 responses were collected, which results in a $5.1 \%$ error rate at $95 \%$ confidence level.

The hydrogen hybrid bus was perceived by the riders as superior to the equivalent diesel bus for smoothness of acceleration and stopping, ride comfort, noise level, and temperature level. Overall, hydrogen was perceived as a good or very good idea by $92 \%$ of the respondents. When provided an open-ended question asking why hydrogen is a good fuel, almost half of the responses were related to its benefits for the environment. When provided an open-ended question asking why hydrogen fuel is a bad idea, $8 \%$ of the responses were related to cost; only $2 \%$ were related to safety concerns.

One interesting result was that as frequency of riding the bus increased, so did the favorable view of hydrogen.

\section{Patterson}

- Patterson, Phil. "Choosing the Best Fuel to Replace Gasoline: Opinion Research Corporation Survey Conducted February 8, 2007.” U.S. Department of Energy (February 2007).

This statistically designed telephone survey of 1,022 adults (1,000 weighted responses) was conducted during February 2007. Respondents were asked to consider a future date when gasoline is no longer available. They were asked their opinions of the best/worst fuel for use in personal vehicles to replace gasoline and were provided three possible options - ethanol, electricity, or hydrogen. For the best fuel, 36\% responded ethanol, 32\% responded electricity, and $25 \%$ responded hydrogen, while $7 \%$ indicated that they did not know. For the worst fuel to replace gasoline, 29\% responded ethanol, 26\% responded electricity, 24\% responded hydrogen, and $20 \%$ indicated that they did not know. The most frequently mentioned reason why hydrogen is best was its environmental benefits. The most frequently mentioned reason why hydrogen is the worst option to replace gasoline was safety. 
The questions in this survey were identical to questions asked in surveys conducted in 2000 and 2004. Figures 3.1 and 3.2 show a comparison of responses over time (Kubik, 2005; Patterson, 2007).

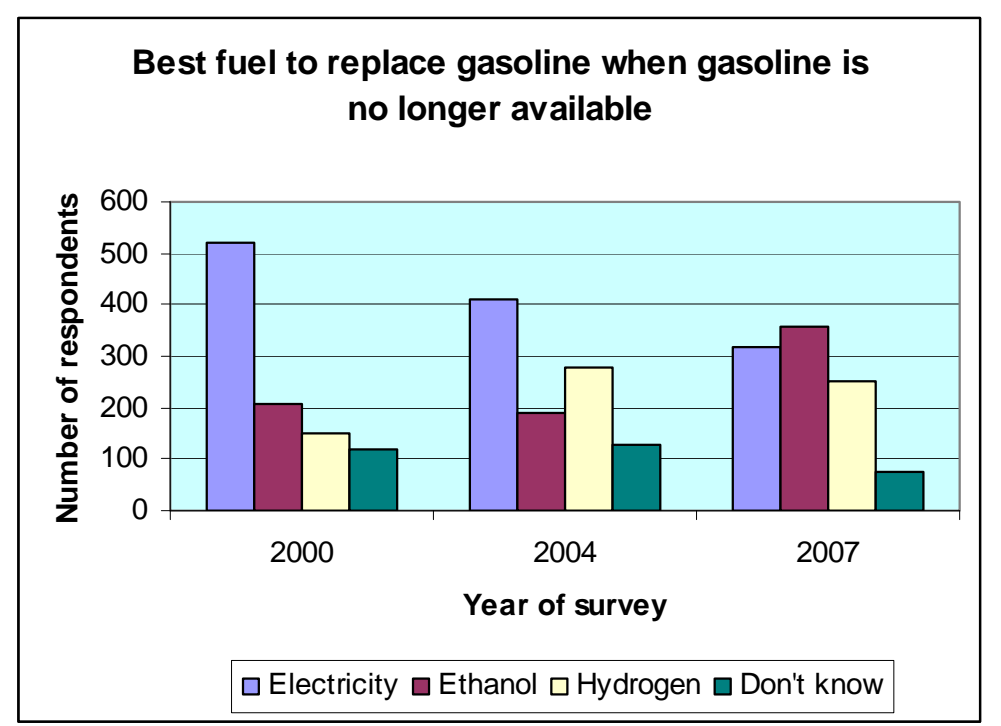

Figure 3.1. A comparison of responses, over time, to a question concerning the best fuel to replace gasoline.

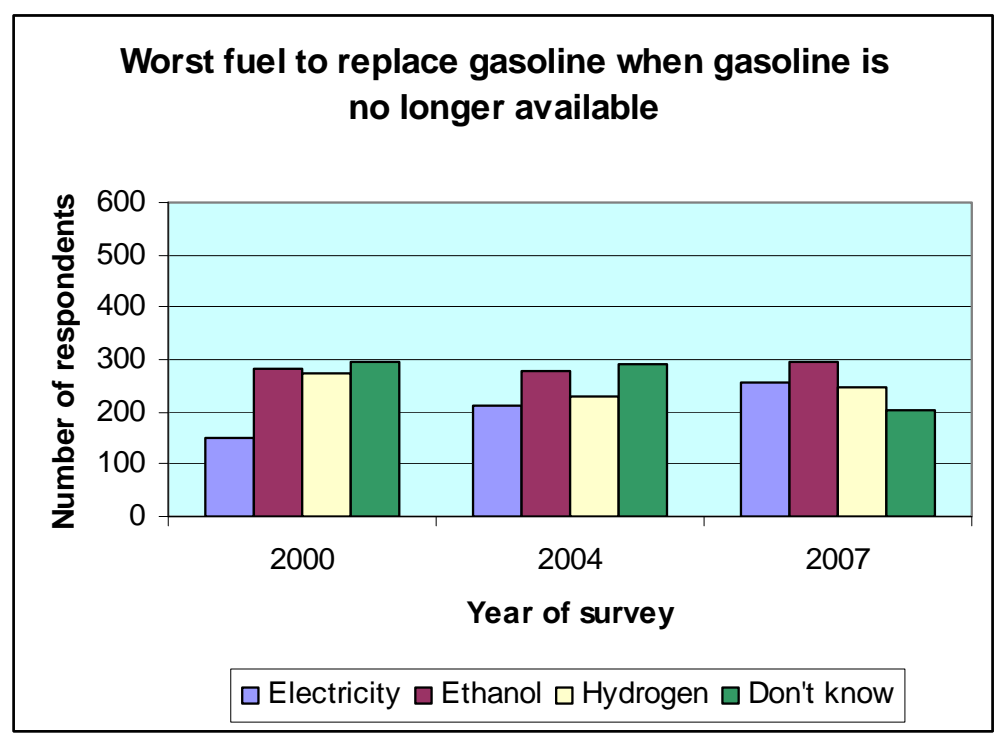

Figure 3.2. A comparison of responses, over time, to a question concerning the worst fuel to replace gasoline.

\section{Shaheen et al.}

- Shaheen, Susan A., Elliot Martin, and Timothy E. Lipman. "Dynamics in Behavioral Response to a Fuel Cell Vehicle Fleet and Hydrogen Fueling Infrastructure: An Exploratory Study.” Submitted to the Transportation Research Record, http://database.path.berkeley.edu/imr/papers/UCD-ITS-RR-07-18.pdf (August 1, 2007). 
The survey subjects consisted of fleet drivers in California and Michigan. Hydrogen fuel-cell vehicles were placed in fleets of for-profit companies. For participation in the survey, criteria required that drivers (1) drive the fuel-cell vehicle at least once a month, (2) drive at least 65 kilometers per month, and (3) be willing to complete the three survey phases. The purpose of the surveys was to determine to what extent drivers' views of the vehicle and fueling changed over time. The focus group discussion elicited further experiences with the fuel-cell vehicle and attempted to determine how these experiences affected participant evaluations of the vehicle.

The fuel-cell vehicle was well received overall by study participants. Higher levels of hydrogen exposure were correlated with greater acceptance in terms of safety. The limited range and fueling infrastructure were noted as limitations that required significant trip planning. The vehicle was considered easy to operate. It was concluded that targeted improvements are required for practical utility of the vehicle before market viability is possible, especially with respect to driving range and infrastructure.

\subsection{FOCUS GROUPS AND NON-SCIENTIFIC POLLS}

Table 3.2 provides an overview of some additional sources that are of interest to the DOE knowledge and opinions surveys.

Table 3.2. Overview and Comparison of Focus Groups and Non-Scientific Polls Included in the 2008 Compendium

\begin{tabular}{|c|c|c|c|c|c|}
\hline Survey & Site & Population & Responses & Format & $\begin{array}{l}\text { Objective } \\
\end{array}$ \\
\hline $\begin{array}{l}\text { Miriam Ricci et al., } \\
2006\end{array}$ & $\begin{array}{l}\text { United } \\
\text { Kingdom }\end{array}$ & $\begin{array}{l}\text { Focus groups } \\
\text { of mixed age, } \\
\text { gender, socio- } \\
\text { economic, and } \\
\text { ethnic } \\
\text { attributes }\end{array}$ & $\begin{array}{l}\text { Nine focus } \\
\text { groups, } \\
\text { each } \\
\text { consisting } \\
\text { of 8-13 } \\
\text { participants }\end{array}$ & $\begin{array}{l}\text { Open } \\
\text { discussions }\end{array}$ & $\begin{array}{l}\text { To understand the } \\
\text { complexity of public } \\
\text { perceptions of } \\
\text { technological issues }\end{array}$ \\
\hline $\begin{array}{l}\text { Bureau de } \\
\text { Normalisation du } \\
\text { Quebec (BNQ) }\end{array}$ & Web site survey & $\begin{array}{l}\text { Companies } \\
\text { interested in } \\
\text { hydrogen } \\
\text { standards }\end{array}$ & Unknown & $\begin{array}{l}\text { Both closed- } \\
\text { and open-end } \\
\text { questions }\end{array}$ & $\begin{array}{l}\text { To obtain input for } \\
\text { updating the ISO/TC } \\
197 \text { business plan }\end{array}$ \\
\hline $\begin{array}{l}\text { CCS Global Group, } \\
2007\end{array}$ & Global input & $\begin{array}{l}\text { Government, } \\
\text { industry, and } \\
\text { nongovernment } \\
\text { organizations }\end{array}$ & $\begin{array}{l}\text { Not } \\
\text { provided }\end{array}$ & Not provided & $\begin{array}{l}\text { Survey of user } \\
\text { perspectives in } \\
\text { preparation for the ISO } \\
\text { Round Table }\end{array}$ \\
\hline $\begin{array}{l}\text { Oracle Education } \\
\text { Foundation }\end{array}$ & Web site survey & $\begin{array}{l}\text { Any one with } \\
\text { access to the } \\
\text { Internet }\end{array}$ & 60 & $\begin{array}{l}\text { Closed-end } \\
\text { questions }\end{array}$ & $\begin{array}{l}\text { To promote an } \\
\text { international policy } \\
\text { discussion on energy } \\
\text { and environmental } \\
\text { issues }\end{array}$ \\
\hline $\begin{array}{l}\text { Peak Oil News \& } \\
\text { Message Board }\end{array}$ & Web site survey & $\begin{array}{l}\text { Any one with } \\
\text { access to the } \\
\text { Internet }\end{array}$ & 373 & $\begin{array}{l}1 \text { closed-end } \\
\text { question and } \\
\text { space for } \\
\text { comments }\end{array}$ & $\begin{array}{l}\text { Responses to "Will } \\
\text { hydrogen ever replace } \\
\text { fossil fuels as our main } \\
\text { energy source?" }\end{array}$ \\
\hline
\end{tabular}




\section{Ricci: Public Attitudes toward Hydrogen in the United Kingdom (UK)}

- Ricci, Miriam, Paul Bellaby, and Rob Flynn. “'Telling It as It Is': Typical Failings in Studies of Lay Opinion about a Hydrogen Economy.” $16^{\text {th }}$ World Hydrogen Energy Conference, Lyon, France (June 2006).

- Ricci, Miriam. Exploring Public Attitudes towards Hydrogen Energy: Conceptual and Methodological Challenges. UK Sustainable Hydrogen Energy Consortium Institute for Social, Cultural and Policy Research, University of Salford. UKSHEC Social Science Working Paper No. 13. http://www.psi.org.uk/ukshec/pdf/Ricci\%20_2006_\%20Exploring\%20Public\%20Attitud es\%20towards\%20hydrogen\%20energy.pdf (January 2006).

- Ricci, Miriam, Rob Flynn, and Paul Bellaby. Public Attitudes Towards Hydrogen Energy: Preliminary Analysis of Findings from Focus Groups in London, Teesside and Wales. UKSHEC Social Science Working Paper No. 28 (June 2006)

- Bellaby, Paul, Paul Upham, et al. Public Engagement with Hydrogen Infrastructures in Transport. DfT Horizon Research Programme - Contract Number PPRO 4/54/2. http://www.iscpr.salford.ac.uk/iscpr/resources/uploads/File/Projects/DfT\%20Executive\% 20Summary.doc (December 2007).

These papers are part of a wider project called UK Sustainable Hydrogen Energy Consortium (SHEC). The consortium asserts that public acceptance (or rejection) of changes to the status quo is critical to success of a hydrogen economy, which is defined as a "complex socio-technical system,” not just a technology.

Ricci notes that most research on public attitudes toward hydrogen has been conducted through questionnaire surveys and that most of these studies have addressed specific applications in the transportation sector. The overriding conclusions have been that there is a low level of public awareness and knowledge of hydrogen technologies; however, the public appears to support introduction of hydrogen as a transportation fuel. Ricci discusses various public responses to new technological developments - responses that range from enthusiasm to opposition. Public attitudes, while generally positive toward new technologies, can quickly erode if people perceive that the information they have been provided has been incomplete or deliberately occluded or if people lose trust in the proponents of the technology.

To contribute to an understanding of the complexity of public perceptions of technological issues, nine focus groups, each of which included eight to thirteen participants of mixed age, gender, socio-economic group, and ethnicity, were conducted between June 2005 and March 2007. Specific issues were addressed and educational information was provided gradually over the one- to two-hour focus group period. Preliminary findings indicate that public perceptions of hydrogen are neither wholly positive nor wholly negative. They are always conditional and contextual. Focus group participants expressed concerns about the safety of hydrogen technologies in terms that were familiar to them and using references to familiar fuels. Participants were, in general, distrustful of governments' willingness to address energy and environmental issues. In some focus groups, a distrust of industry also emerged. Differences of opinions were obvious among the stakeholders - for example, between local authorities and industrial participants. 
Based on the focus group discussions, hydrogen experts and lobbying groups that tend to frame the debate over a hydrogen future in terms of its safety risks should be looking at a broader set of issues. Safety is an important, but not exclusive, component of public acceptance.

Twelve additional focus groups were described and selected for further study. After viewing a short documentary film on hydrogen energy as part of a "whole system," participants reiterated concerns about risks, expressed a lack of trust in business and government, and noted that knowledge is low.

\section{Bureau de Normalisation du Quebec (BNQ)}

BNQ (Bureau de Normalisation du Quebec). ISO/TC 197 Survey. "Hydrogen Industry Survey.” http://www.bnq.qc.ca/en/formulaire_hydrogene.html (copyright 2004).

In 2004, the BNQ issued a web-based survey to obtain input prior to updating the International Organization for Standardization Technical Committee (ISO/TC) 197 business plan. Survey questions cover awareness of the ISO/TC 197 activities, international standardization activities, and market information. No results of this survey were available. The importance of this survey to DOE is the audience that is addressed by the survey. The plan for the $2008 / 2009$ DOE surveys is to include a survey of safety and codes officials.

\section{CCS Global Group}

Dey, Randy. CCS Global Group, “4.1 Hydrogen User Perspectives and Feed-back,” http://www.iso.org/iso/4.1_hydrogen_perspectives_dey.pdf . Survey in preparation for the ISO Round Table, January 10, 2007, Geneva.

In preparation for the ISO Round Table, January 10, in Geneva, CCS conducted a non-scientific survey. Respondents included government, industry, and nongovernment organizations with fields of operations including automotive, energy, and infrastructure with a global market target. These results are important to the DOE survey because respondents, 95\% of which were familiar with ISO, felt that standardization is currently needed in many areas involving hydrogen and fuel cell technologies. Respondents (75\%) also noted that there is no need to wait until technology is further advanced before developing codes and standards.

\section{ORACLE Education Foundation}

- ORACLE Education Foundation. 2000 ThinkQuest Internet Challenge. "From Carbon to Hydrogen Energy.” Section 5: Visitor Survey - Summary Report.

http://library.thinkquest.org/C005858/survey.html .

This non-scientific survey was part of a student project to elicit an international policy discussion on the following question: "Should the world move from a carbon fossil fuel energy economy to a hydrogen based energy economy?” While not a statistically designed survey, the results were interesting. One question asked whether the media in the country of the respondent was 
addressing hydrogen issues. Of a total of 60 responses to this question, $60 \%$ of the respondents indicated that they had never heard of the issue or had only heard of it once or twice.

\section{Peak Oil News \& Message Boards}

Peak Oil News \& Message Boards. http://www.peakoil.com/survey40-results.html .

This non-scientific, web-based survey recorded responses to the question, "Will hydrogen ever replace fossil fuels as our main energy source?” As of May 29, 2007, there was a total of 373 votes, of which $15 \%$ were Yes, $75 \%$ were No, and $10 \%$ were Unsure.

\subsection{SURVEY METHODOLOGY}

Sections 3.1 and 3.2 summarize conclusions of recent studies about hydrogen knowledge and opinions. The methodologies for arriving at the conclusions include computer assisted telephone interview (CATI) surveys, face-to-face interviews, computer-based questionnaires completed electronically, and focus groups. It is beyond the scope of this report to detail the methodology employed in each study or to consider survey methodology in general. The CATI and random digit dialing (RDD) survey methodology used to conduct the DOE hydrogen knowledge assessment surveys has been employed for many years. Its strengths and weaknesses have been studied, and telephone survey researchers (and the U.S. Office of Management and Budget) are aware of them. For example, over the last thirty years, coverage rates (the proportion of the target populations actually sampled) have been high in CATI RDD surveys because nearly all of the target populations have had landline telephones. On the other hand, response rates in CATI surveys have often been low (e.g., less than 25\%). However, despite low response rates, because of inherent efficiency and low costs, CATI surveys have been a method of choice in survey research.

In the last few years, however, there has been a sudden decline in the coverage rate in landline telephone surveys because of steep increases in the proportion of "cell-phone-only" individuals. This issue is discussed in recent publications including

- Blumberg, Stephen J., Luke, Julian V., and Cynamon, Marcie L. “Telephone Coverage and Health Survey Estimates: Evaluating the Need for Concern about Wireless Substitution,” American Journal of Public Health, 96(5) (May 2006).

- Lavrakas, Paul J., Shuttles, Charles D., Steeh, Charlotte, and Fienberg, Howard. “The State of Surveying Cell Phone Numbers in the United States, 2007 and Beyond," Public Opinion Quarterly, 71(5), 840-854 (2007).

- Link, Michael W., et al. "Practicability of Including Cell Phone Numbers in Random Digit Dialed Surveys: Pilot Study Results from the Behavioral Risk Factor Surveillance System,” http://www.fcsm.gov/07papers/Link.II-C.pdf (accessed 2008). 
- ZuWallack, Randal S. "Piloting Data Collection via Cellular Phones: Results, Experiences, and Lessons Learned,” Macro International Inc. (white paper), http://www.orcmacro.com/Survey/CellPhone/Cell\%20phone\%20white\%20paper.pdf (September 2007).

According to Blumberg (author of the first reference cited above), "If the compound growth rate in 2007 and 2008 remains as it was in 2003-2006, then more than 25\% of U.S. households will only have cell phones during the second half of 2008." 5 The cell-phone-only problem is thus becoming substantial.

According to the above sources, cell-phone-only individuals are most frequently in the 20-35 age bracket. Corrections for under-sampling this age bracket can be made by assigning higher poststratification weights (a weighting adjustment in the data analysis) to individuals in this age group. However, age-based weighting corrections cannot be used to properly adjust for inherent differences between cell-phone-only and landline individuals of the same age. Furthermore, it is reasonable to speculate that cell-phone-only individuals could be more aware of technology in general (and thus hydrogen technology in particular) than individuals with landline phones only or even both landline and cell phones. Failure to address the cell-phone-only coverage deficiency in traditional landline surveys could thus be a concern in the DOE hydrogen technology awareness survey, particularly the RDD surveys of the general public and students.

An obvious remedy to the cell-phone-only coverage issue is to supplement traditional CATI RDD landline phone surveys with cell-phone components. However, obstacles to cell-phone supplements include imposition on respondents, who bear cell phone usage costs in "minutes," and laws such as the federal Telephone Consumer Protection Act, which requires that unsolicited calls to cell phones have to be dialed by hand rather than a computer. How to properly weight cell-phone-only, cell-and-landline, and landline-only respondents in a combined survey is also the subject of current research.

These issues are being addressed by survey research firms and in big survey studies such as the Behavioral Risk Factor Surveillance System (third bullet above), the world's largest ongoing public health telephone survey. It is not feasible to address the cell-phone-only issue in the 2008 DOE hydrogen knowledge assessment surveys. However, it is very likely that methodology will have been developed by 2011. Because of continued increases in the number of cell-phone-only individuals, the issue will have to be addressed for the 2011/2012 DOE surveys.

\footnotetext{
${ }^{5}$ See http://www.pollster.com/blogs/cell_phones_and_political_surv.php.
} 


\section{SUMMARY AND CONCLUSIONS}

This report is an update to a 2003 literature review of knowledge and opinions on hydrogen and fuel cell technologies. The sources are briefly summarized with the purpose of gleaning those facts that are important to the DOE surveys that will be conducted in the 2008/2009 timeframe. The DOE surveys are statistically designed and analyzed and do not include focus groups; however, findings from focus groups and non-scientific surveys are included in this report for background information. In addition, survey methodology is discussed, particularly with respect to changes that are becoming necessary because of recent increases in numbers of "cell-phoneonly" individuals, who are not covered in traditional landline telephone surveys.

Eight statistically designed surveys conducted in Europe were summarized. The Eurobarometer and AcceptH2 surveys are updates (with slight modifications) to surveys reported in the 2003 literature review. All survey respondents were adults. Most of the surveys addressed public opinions and social acceptance of hydrogen.

The Eurobarometer surveys address energy-related issues, and hydrogen issues are mentioned only in the context of energy. Europeans are concerned about climate change and are in favor of renewable energy sources. The Eurobarometer study found that respondents trusted scientists and environmental protection organizations but not the government or political parties.

The AcceptH2, Haraldsson, and Maack surveys questioned persons who had some experience with fuel cell buses. Results of the AcceptH2 surveys indicated that persons were more knowledgeable after fuel cell demonstration projects than before and were quite positive toward the use of hydrogen buses. The Haraldsson study found that bus passengers obtained their information from newspapers and information at the bus stops. While a majority of the passengers thought that the technology was safe and the buses were comfortable, they were not willing to pay a higher fee for the hydrogen buses. The Maack study confirmed the results of the Haraldsson study in that respondents were very positive about the characteristics, including safety, of hydrogen buses; however, any additional costs for riding hydrogen buses must be kept to a minimum.

One poll in Great Britain (Society of Motoring Manufacturers and Traders) examined women's roles in the purchase of an automobile. This study concluded that women were more concerned with price, appearance, and brand than safety features and low carbon emissions.

Studies conducted in the Netherlands by the Delft University of Technology examined the impact of biased information (positive, negative, neutral) on respondents and concluded that the biased text impacted opinions (as expected). This study also found that hydrogen technical knowledge is not high, but that willingness to use hydrogen was rather high. The authors noted that more highly educated respondents have more knowledge about hydrogen and a higher acceptance.

Research conducted in Norway on "pseudo-opinions" studied general methodologies of knowledge and opinions surveys. After responding to a set of highly technical knowledge 
questions, respondents were asked to provide opinions. Although the respondents lacked understanding of the technologies and indicated that, in some cases, they had never heard of the technologies, they did not hesitate to provide opinions about (evaluations of) the technologies. The authors noted that these opinions are unstable and should not be used to guide policy decisions.

Seven statistically designed surveys conducted in North America were summarized. One of these is the DOE surveys conducted in 2004, the precursor to the 2008/2009 DOE surveys. Another is an update to a survey reported in the 2003 literature review.

The 2004 DOE surveys were more extensive than the other surveys, covering four different population groups. Hydrogen knowledge was low in all groups except state and local government officials. In addition, there was a direct correspondence between hydrogen knowledge and opinions about hydrogen safety.

Two studies assessed opinions based on experience with hydrogen vehicles. Riders on a hybrid hydrogen bus in Canada rated the comfort of the hydrogen bus as superior to the equivalent diesel bus. Hydrogen fuel-cell vehicles were placed in two fleets in the United States. Drivers indicated that the greatest limitations to the vehicles were their limited driving range and fueling infrastructure.

One survey requested input on issues related to hydrogen policy decisions. Most of the responses were from the United States; the U.S. Department of Energy was named most often as the organization that was most influential on policies related to hydrogen. The importance of this survey to the DOE hydrogen and fuel cell knowledge and opinions surveys are findings related to the direction of hydrogen education programs. The respondents felt that the top three education targets (population group - technology) should be (1) consumers - the economic value of hydrogen vehicles; (2) government agencies - societal and environmental benefits of hydrogen; and (3) safety and permitting officials - issues related to hydrogen safety.

Three surveys explored attitudes and opinions on energy policies, emerging technologies, and alternative fuels. Each survey slanted the questions in a slightly different angle. In general, respondents were concerned about U.S. energy policy. Respondents to the GM survey indicated that the U.S. government should fund a transformation of the auto industry into a hydrogenbased system; however, there is significant opposition to increasing the gas tax to fund this effort. Respondents to the TNS survey indicated that they thought that auto/oil company agendas, public awareness, and high costs are the greatest hindrances to progress on alternative fuels. The TNS survey found that knowledge about hydrogen and fuel cells increases with education level. Finally, the Patterson survey requested input regarding the best and worst fuels to replace gasoline. With only three choices - ethanol, electricity, or hydrogen - respondents placed hydrogen in third place as the best choice.

Since the literature review of 2003, in which seven primary sources were cited for statistically designed surveys, there have been 15 new surveys that are of interest to the DOE Hydrogen Education Subprogram. The fact that there have been significantly more studies implies that 
there have been an increased number of demonstration projects and/or additional interest in hydrogen and fuel cell technologies.

The most relevant findings of these 15 surveys, all of which were conducted in Europe (E) or North America (NA), to the DOE surveys are as follows:

1. Respondents who are more educated are more accepting of hydrogen technologies (NA).

2. Respondents who are more knowledgeable about hydrogen and/or fuel cells are more accepting of hydrogen technologies (E, NA).

3. When asked about issues of trust, respondents generally expressed distrust of the government or political parties but trusted scientists and environmental protection organizations (E).

4. Technical knowledge about hydrogen and fuel cell technologies is low (E, NA).

5. Respondents may express opinions about a technology even when they are lacking in knowledge of that technology (E).

6. Women and men have different priorities when deciding on an automobile purchase (E).

7. Public acceptance to hydrogen is vulnerable to perceptions of decreased safety (E, NA).

8. Public acceptance to hydrogen is vulnerable to perceptions of increased cost (E, NA).

In addition to the primary sources, six non-scientific surveys were discussed. One of these, a well-designed study involving focus groups with carefully designed participation, concluded that government leaders should be discussing a broader set of hydrogen issues than just safety concerns. Safety is an important, but not exclusive, component of public acceptance of hydrogen technologies. Two additional surveys, both internet based, solicited input concerning ISO hydrogen standards. The primary impact of one of the surveys was that standardization is currently needed in many areas.

The DOE hydrogen and fuel cell knowledge and opinions surveys are similar to surveys reviewed in Sections 3.1 and 3.2 which examine technical knowledge of hydrogen and fuel cell technologies, although the technical questions are different. The DOE surveys are also similar to the opinion surveys in that they address many of the same issues, such as safety, sources of energy information, and trust.

There are many differences between the DOE surveys and the surveys reviewed in Sections 3.1 and 3.2. All of the DOE surveys are conducted via telephone interviews, while many of the surveys above are conducted face-to-face or via electronic means. DOE will survey five different populations (general public, students, government agencies, end users, and safety and codes officials). No survey (except the DOE survey) conducted since 2003 surveyed students' knowledge and opinions of hydrogen and fuel cells. In addition, although several surveys have solicited opinions of "users" (passengers and drivers of hydrogen/fuel-cell vehicles), no surveys were conducted of "end users" (industrial users needing large power supplies, commercial users needing uninterrupted power, or transportation businesses). Finally, while the ISO has surveyed its membership concerning the need for standards, the general population of safety and codes officials has not been surveyed. Therefore, the DOE surveys are the ONLY surveys of these population groups covering knowledge and opinions for hydrogen and fuel cell technologies. 
The greatest impact and importance of the DOE surveys is that five distinct population groups are surveyed, using statistically designed survey methods, for both knowledge and opinions on hydrogen and fuel cells. Knowledge levels can be computed for each population group and can be compared across the populations and across time. Opinions can be compared with knowledge levels. A baseline of knowledge levels was derived using the results of the 2004 surveys; this baseline will be compared with the results of the knowledge evaluation for the surveys of 2008/2009 and 2011/2012. The DOE knowledge and opinions surveys are unique in coverage and purpose.

It must be noted, however, that response rates for telephone surveys have decreased dramatically over time. Developments in survey methodology research will have to be followed over the next few years so that necessary adjustments are made in the 2011/2012 DOE hydrogen survey design, to account for cell-phone-only individuals as well as other changes in telephone usage demographics. 


\section{REFERENCES}

Kubik, M., Consumer Views on Transportation and Energy (Second Edition), NREL/TP-62936785, http://www.nrel.gov/docs/fy06osti/39047.pdf .April 2005,

Patterson, Phil. "Choosing the Best Fuel to Replace Gasoline: Opinion Research Corporation Survey Conducted February 8, 2007.” U.S. Department of Energy (February 2007).

Schmoyer, Rick, Tykey Truett, and Christy Cooper, Results of the 2004 Knowledge and Opinions Surveys for the Baseline Knowledge Assessment of the U.S. Department of Energy Hydrogen Program, ORNL/TM-2006/417, April 2006.

Truett, Tykey, Literature Review for the Baseline Knowledge Assessment of the Hydrogen, Fuel Cells, and Infrastructure Technologies Program, ORNL/TM-2003/258, October 2003.

(U.S. DOE/DOT) United States Department of Energy and United States Department of Transportation, Hydrogen Posture Plan, an Integrated Research, Development and Demonstration Plan, http://www.hydrogen.energy.gov/pdfs/hydrogen_posture_plan_dec06.pdf, December 2006. 